\title{
U.S. Population Growth Continues to Slow Due to Fewer Births and More Deaths
}

Kenneth M. Johnson

$\mathrm{T}$ The U.S. population grew by just 2,020,000 or 0.62 percent between July 2017 and July 2018 according to recent Census Bureau estimates. This is the lowest population growth rate since 1937. A major contributor to the nation's recent low growth rate is the diminishing surplus of births over deaths-what demographers call natural increase. There were just 1,041,000 more births than deaths last year, the smallest natural increase in more than 70 years. When fewer babies are born and more deaths occur, population growth slows. Last year, there was a record number of deaths $(2,814,000)$, but relatively few births $(3,856,000)$. Just ten years ago, the surplus of births over deaths was 44 percent higher $(1,860,000)$. This dwindling excess of births over deaths is occurring nationwide. Natural increase diminished in all but North Dakota and the District of Columbia over the past ten years. The reduction was substantial in many states; twelve experienced at least a 60 percent reduction in natural increase during this period and another twenty-four experienced declines of 40 to 60 percent. In West Virginia and Maine, more people are now dying than being born. The sharp reductions in natural increase make states increasingly dependent on migration to fuel significant population growth. And, in the nine states without sufficient natural increase to offset migration losses, the population declined last year.

\section{EXCESS OF BIRTHS OVER DEATHS HAS DIMINISHED SHARPLY IN RECENT YEARS}

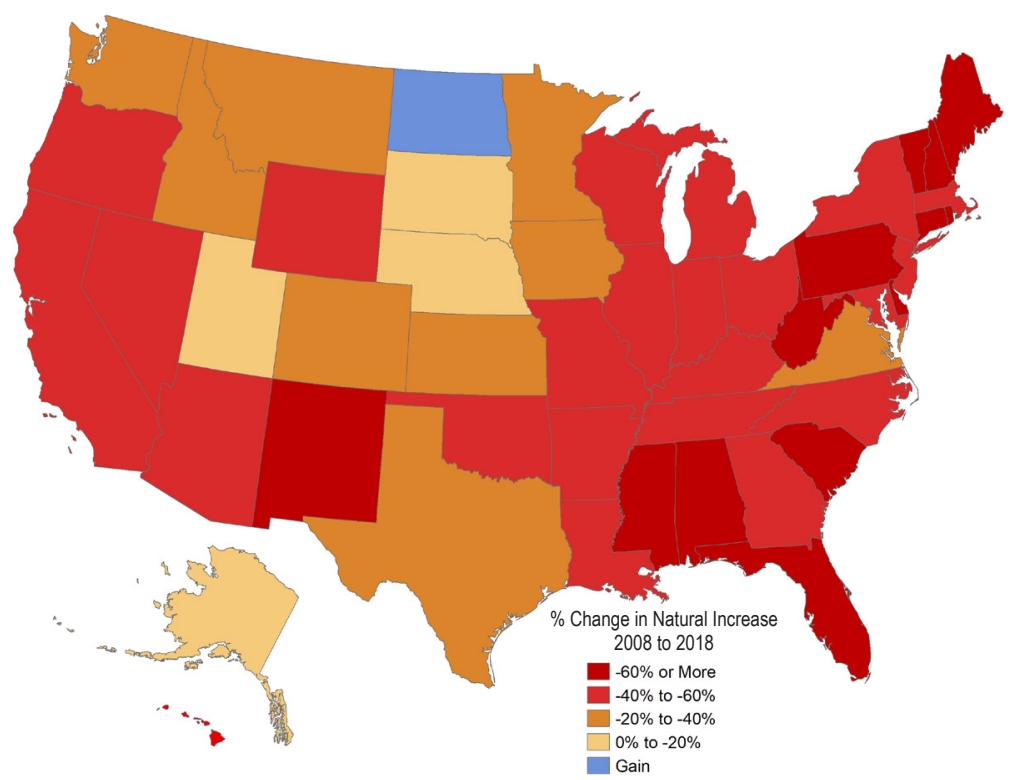

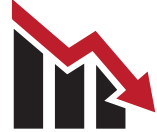

In the United States, fewer births and more deaths has reduced population growth. In many states, the surplus of births over deaths has sharply diminished.

See Related Publications at carsey.unh.edu

- Ten Years After the Great Recession Began, U.S. Birth Rate Is at Record Low (September 2018)

- Domestic Migration and Fewer Births Reshaping America (March 2018)

\footnotetext{
About the Author

Kenneth M. Johnson is Senior Demographer at the Carsey School of Public Policy, professor of sociology at the University of New Hampshire, and an Andrew Carnegie Fellow. This research was supported by his Andrew Carnegie Fellowship and the New Hampshire Agricultural Experiment Station. The content is solely the responsibility of the author and does not necessarily represent the official views of the sponsoring organizations.
} 